\title{
Specific Binding of Antigen onto Human T Lymphocytes
}

\author{
A. Durandy, A. Fischer, D. Charron, ${ }^{*}$ and C. Griscelli \\ Institut National de la Santé et de la Recherche Médicale Unité 132, Hôpital Necker-Enfants Malades, 75743 Paris \\ Cedex 15; *Centre National de la Recherche Scientifique Formation de recherche associée 500, Laboratoire d'Immunogénétique \\ Humaine, Centre Hospitalier Universitaire Pitié-Salpétrière, 75013 Paris, France
}

\begin{abstract}
Human T lymphocytes sensitized to Candida albicans (CA) were shown to proliferate in cultures induced with mannan, a ramified polysaccharide extracted from the cell well of CA. We presently describe that, when we used strongly labeled [ ${ }^{3} \mathrm{H}$ ]mannan, antigen-specific $\mathbf{T}$ blast cells were able to bind the labeled mannan on their membrane. The observations that irrelevant blast cells did not bind $\left[{ }^{3} \mathrm{H}\right]$ mannan, and that mannan-specific blast cells did not bind tritiated pneumococcal polysaccharide SIII, indicate the specificity of mannan binding. Mannan binding was reversible and saturable. Mannan binding on $T$ blast cells was inhibited by preincubation with monoclonal antibodies to $\mathrm{T} 3$ but not to other $T$ cell-related molecules. The characteristics of this receptor suggest its identity with the $T$ cell receptor for antigen. The direct binding of mannan could be either due to a cross-linking of the receptor by multivalent mannan or to a recognition of mannan in association with HLA-DQ molecules, as suggested by partial blocking of mannan binding using anti-HLA-DQ monoclonal antibodies.
\end{abstract}

\section{Introduction}

Many studies have attempted to identify directly the membrane receptors for the binding of antigen onto specifically activated $T$ cells. Research performed on murine or human models has suggested direct binding of antigen alone onto primed $\mathrm{T}$ cells (1-7). However, most reports have shown that $T$ lymphocytes recognize the antigen in association with a major histocompatibility complex (MHC) ${ }^{1}$ product, and not alone (8-12).

We have previously described a specific in vitro system of antibody production to mannan of Candida albicans by sensitized human lymphocytes (13). This system provided the opportunity for studying the membrane expression of structures able to bind specifically this polysaccharidic antigen. We used labeled $\left[{ }^{3} \mathrm{H}\right]$ mannan, which provided a sensitive method for detecting mannan binding on activated $T$ and $B$ blast cells obtained in specifically stimulated cultures. We studied the relationship

Received for publication 29 July 1985 and in revised form 15 January 1986.

1. Abbreviations used in this paper: $\mathrm{Ab}$, antibody; $\mathrm{ACC}$, antibody-containing cells; CA, Candida albicans; ELISA, enzyme-linked immunosorbent assay; ICC, immunoglobulin-containing cells; IL-2, interleukin 2; MAb, monoclonal antibody; MBSA, methylated bovine serum albumin; MHC, major histocompatibility complex; PHA, phytohemagglutinin; PWM, pokeweed mitogen; sIg, surface immunoglobulin; SIII, pneumococcal polysaccharide SIII; TdR, thymidine.

J. Clin. Invest.

(c) The American Society for Clinical Investigation, Inc. 0021-9738/86/05/1557/08 $\$ 1.00$

Volume 77, May 1986, 1557-1564 between mannan binding to $\mathrm{T}$ blast cells and glycoproteins expressed on $\mathrm{T}$ lymphocyte membranes, such as the T3 complex, which has been previously shown to be associated with the receptor for antigen on proliferative, helper, and cytotoxic $\mathrm{T}$ cell clones $(11,12,14)$. The results presently reported indicate the existence on mannan-activated $T$ lymphocytes of a mannan specific-receptor associated with the T3 complex.

\section{Methods}

Polysaccharide antigens. The antigen used was extracted from Candida albicans (CA) strain A, by a technique previously described (13) and modified from that described by Summers et al. (15). It contained, after purification, $3.4 \%$ protein, traces of glucan, and $>96 \%$ mannan. Its molecular weight was $\sim 8,000$. Mannan composed of D-mannose residues ramified with $\alpha 1-2, \alpha 1-3, \alpha 1-4$, and $\alpha 1-6$ linkages (16). This preparation will henceforth be called mannan because the polysaccharide was the main component of the antigen preparation. Mannose was obtained from Sigma Chemical Co., St. Louis, MO). Oligomannosides (two to four mannose residues with $\alpha 1-2, \alpha 1-3$ linkages) were prepared by Dr. J. Montreuil (Lille, France). Purified linear mannan from Klebsiella K1 strain Kasuya (03:K1) composed of $\alpha 1-2, \alpha 1-3$ linkages was kindly provided by Dr. V. Kato (Osaka, Japan). Another unrelated polysaccharide, the pneumococcal polysaccharide SIII (SIII) $(350,000 \mathrm{~mol} \mathrm{wt})$ purified as described by Felton et al. (17) was used as a check.

Mannan was tritiated by L. Pichat (Commissariat à l'Energie Atomique, France) by catalytic exchange in solution with tritium $\left({ }^{3} \mathrm{H}\right)$ as described by Evans et al. (18). Analysis of $\left[{ }^{3} \mathrm{H}\right]$ mannan by acid hydrolysis and paper chromatography revealed that any and all radioactivity was bound to mannose, with a specific activity of $2 \mathrm{mCi} / \mu \mathrm{g}$. SIII was similarly labeled $(1.5 \mathrm{mCi} / \mu \mathrm{g})$.

Cell cultures. Blood samples were obtained from healthy adult volunteers, newborn infants, and X-linked agammaglobulinemic patients. Blood donors were considered as sensitized to Candida albicans when a candidin (Institut Pasteur, Paris, France; $50 \mu \mathrm{g} / \mathrm{ml}$ )-induced proliferation was observed. In normal sensitized donors, specific serum antibodies to mannan were also found when using an enzyme-linked immunosorbent assay (ELISA). Peripheral blood lymphocytes (PBL) were isolated on a Ficoll-Hypaque (Pharmacia Fine Chemicals, Uppsala, Sweden) density gradient and washed twice in Hanks' solution. PBL were cultured in flat-bottomed microtiter wells (Falcon Plastics, Becton, Dickinson \& Co, Oxnard, CA) at $2 \times 10^{5}$ in $0.2 \mathrm{ml}$ of RPMI 1640 (Gibco, Glasgow, Scotland) culture medium supplemented with $10 \%$ heat-inactivated fetal calf serum (Microbiological Associates, Bethesda, MD), antibiotics (penicillin $100 \mathrm{IU} / \mathrm{ml}$, streptomycin $0.1 \mathrm{mg} / \mathrm{ml})$, amphotericin B $(4 \mu \mathrm{g} / \mathrm{ml})$, and glutamine $(0.3 \mu \mathrm{g} / \mathrm{ml}$, Institut Merieux, Lyon, France). Cultures were incubated with $40 \mu \mathrm{g} / \mathrm{ml}$ of mannan extemporaneously absorbed on methylated bovine serum albumin (MBSA, Sigma Chemical Co.) at a ratio of 4:1 (13) or coupled on latex beads as described by Gettner and Mackenzie (19). Coupling of mannan was required to obtain specific $T$ cell activation, suggesting a need for high epitopic concentration not provided by soluble mannan (13). Cultures were also initiated with pokeweed mitogen ([PWM] Gibco, $5 \mu \mathrm{l} / \mathrm{ml}$ ) or antigens (SIII $100 \mu \mathrm{g} /$ $\mathrm{ml}$, tetanus toxoid $100 \mu \mathrm{l} / \mathrm{ml}$, or Toxoplasma gondii $10 \mu \mathrm{g} / \mathrm{ml}$ ) using PBL from sensitized subjects. Cultures were harvested at days 3,5 , and 7. In cultures maintained longer than $3 \mathrm{~d}$, medium was removed at day 3 and replaced by fresh medium without addition of antigen. The har- 
vested cells were then washed, and viable cells were counted by trypan blue exclusion and tested in suspension for several membrane markers. They were then cytocentrifuged $\left(200 \times 10^{3}\right.$ per slide $)$ and fixed in ethanol. Examination of the smears after staining by methyl green pyronine allowed the evaluation of the percentage of recovered blast cells. Blast cells were defined under microscopic examination as large pyroninophilic cells $(>30 \mu \mathrm{m})$ and/or as cells incorporating tritiated thymidine $\left(\left[{ }^{3} \mathrm{H}\right] \mathrm{TdR}\right)$ in a $1-\mathrm{h}$ incubation $(2 \mu \mathrm{Ci} / \mathrm{ml}$, specific activity $1 \mathrm{mCi} / \mathrm{mmol})$ on radioautographic smears (K5, Ilford, Essex, England). The immunoglobulincontaining cells (ICC) were detected by intracytoplasmic immunofluorescence using fluorescein-labeled anti- $\mu,-\gamma,-\alpha$, or $-\delta$ human heavychain antisera (Nordic Laboratories, Tilburg, The Netherlands). The antimannan antibody-containing cells (ACC) were revealed as previously described (13) by radioautography after specific intracytoplasmic binding of $\left[{ }^{3} \mathrm{H}\right]$ mannan. Fixation of labeled mannan was observed after an $8-\mathrm{d}$ exposure. In most experiments, immunofluorescence and radioautography techniques were used on the same smears, allowing an analysis of the antibody-producing cells. Supernatant antibodies were detected by an ELISA using specific alkaline phosphatase-coupled goat anti-human IgM or IgG (Miles Laboratories, Yeda, Israel). Antibody concentrations were expressed as $\log 2$ dilution of a reference serum from a CA-sensitized subject. A straight line was observed when logit transformed OD 405 was plotted against $\log 2$ of dilution. One unit was arbitrarily defined as the amount of antimannan-specific IgM or IgG present in a 1:10,000 dilution of the reference serum (13).

Cell separation. Monocytes were prepared by a 1-h incubation at $37^{\circ} \mathrm{C}$ of PBL on plasma-coated petri dishes (Nunclon, Gibco), removed by scratching off the plates with a rubber policeman and irradiated to 4,000 rads. This monocyte-enriched preparation contained $>80 \%$ of OKM1(+) cells. Nonadherent cells were filtered on a Sephadex G10 column, then allowed to form $E$ rosettes with neuraminidase-treated sheep red blood cells. $\mathrm{E}(+) \mathrm{T}$-enriched preparations contained $93.1 \pm 6.5 \%$ OKT3(+) cells and E(-) B-enriched preparations contained $70.5 \pm 11.9 \%$ surface Ig $(\mathrm{sIg})(+)$ lymphocytes (20). The complete depletion of T lymphocytes $(<0.1 \%)$ in these B-enriched preparations was achieved by a cytotoxicity assay, using OKT3 and rabbit complement (Sera Laboratories, Sussex, England).

$T$ cell lines. PBL from sensitized donors were cultured with mannanMBSA $(50 \mu \mathrm{g} / \mathrm{ml})$ or influenza virus $(5 \mu \mathrm{g} / \mathrm{ml})$. After $7 \mathrm{~d}$, the cells were recultured at a concentration of $1 \times 10^{5} / \mathrm{ml}$ in RPMI 1640 containing $10 \%$ fetal calf serum supplemented with interleukin 2 (IL-2)-containing medium diluted to an optimal concentration. IL-2 medium was prepared by culturing $1 \times 10^{6}$ pooled human PBL from different donors with 2 $\mu \mathrm{g} / \mathrm{ml}$ phytohemagglutinin (PHA) in RPMI $1640+5 \%$ human serum for $48 \mathrm{~h}$. PHA was removed from IL-2 medium by passage over a column of Sepharose 4B to which rabbit anti-PHA antibodies had been coupled (21). IL-2 medium was filtered and stored at $-20^{\circ} \mathrm{C}$. Every $3-4 \mathrm{~d}$, medium was removed by centrifugation and cells were reseeded at $1 \times 10^{5} / \mathrm{ml}$ in fresh IL-2 medium, and every week 4,000 rad-irradiated autologous PBL and antigen were added. All $\mathrm{T}$ cell lines were tested 4-8 wk after having been initiated. The phenotype of these $\mathrm{T}$ cells was $>90 \% \mathrm{~T} 3(+), \mathrm{T} 4(+)$, and $>75 \%$ HLA class II( + ). Antigen-specific proliferation of $\mathrm{T}$ cell lines was performed as followed: $1 \times 10^{4} \mathrm{~T}$ cells were cultured with $5 \times 10^{4}$ 4,000 rad-irradiated autologous $\mathrm{PBL}$ in presence of influenza virus $\mathrm{A}$ / Bangkok $(0.5 \mu \mathrm{g} / \mathrm{ml})$ or mannan-MBSA $(50 \mu \mathrm{g} / \mathrm{ml})$ in flat-bottomed microtiter wells for $3 \mathrm{~d}$ at $37^{\circ} \mathrm{C}$ in $5 \% \mathrm{CO}_{2}$ incubator. $\left[{ }^{3} \mathrm{H}\right] \mathrm{TdR}$ was added $18 \mathrm{~h}$ before harvest. $\left[{ }^{3} \mathrm{H}\right] \mathrm{TdR}$ uptake was counted in a scintillation counter. A positive control of proliferation consisted in the addition of IL-2 medium alone.

Polyclonal or monoclonal antibodies. Monoclonal antibodies (MAbs) to T3, T4, T8, and T11 molecules expressed by T lymphocytes (22) were obtained from Ortho Pharmaceutical (Raritan, NJ) as well as OKM1 MAb recognizing nonlymphoid leukocytes (23). One other MAb against T3 molecule (UCHT1) was a generous gift of P. Beverley (24). Seven MAbs directed against MHC class II products were also used: MAb antiHLA-DR, OKlal from Ortho Pharmaceutical (25), and D1-12, or F(ab)'2 fragments of D1-12, and two MAbs anti-HLA-DQW1 (BT 3/4 and SDR1) and one MAb anti-HLR-DQ from Becton, Dickinson \& Co., leu 10 (26).
MAbs to $\beta_{2}$-microglobulin (0.18) and to HLA class I antigens (W-6/32) were obtained from Sera Laboratories and used as controls (27).

Leukocyte markers. Membrane leukocyte markers were studied on suspensions of live cells. B lymphocyte markers were detected by surface immunofluorescence using rhodamine-labeled goat $F(a b)^{\prime} 2$ fragments to human $F(a b)$ IgG or to human heavy chains $(\mu, \gamma$, or $\alpha)$ (Nordic Laboratories). Membrane IgD-bearing cells were detected by a fluoresceinlabeled goat antiserum against human $\delta$-chains (Nordic Laboratories). $T$ lymphocytes were enumerated by using anti-T cell MAb in an indirect immunofluorescence test requiring a tetramethyl rhodamine isothiocyanate (TRITC)-labeled antiserum goat anti-mouse immunoglobulin (GAMIg) (Nordic Laboratories). Membrane HLA antigens and $\beta_{2}$-microglobulin were detected by an indirect immunofluorescence assay using the MAb against HLA antigens or $\beta_{2}$-microglobulin. The receptors for FC fragments of IgG were detected by rosetting with ox red blood cells sensitized with specific rabbit IgG antibodies (28) and by immunofluorescence using rabbit or mouse heat-aggregated $\left(30 \mathrm{~min}, 63^{\circ} \mathrm{C}\right) \mathrm{IgG}$. Monocytes were revealed by $\mathrm{OKM} 1$ and by phagocytosis of latex beads.

Mannan-binding to cell membranes. Membrane antigen fixation was studied on cells in suspension by incubation for $1 \mathrm{~h}$ at $4^{\circ} \mathrm{C}$ with $\left[{ }^{3} \mathrm{H}\right]$ mannan $\left(0.1 \mu \mathrm{g} / 10^{5}\right.$ cells). Cells were then washed three times and cytocentrifuged for radioautography. The percentage of membrane-labeled cells was established after an 8-d exposure in emulsion. Cells were considered as positive when labeled with more than 50 silver grains.

In order to characterize the membrane phenotypes of mannan-binding blast cells, microscopic immunofluorescence was coupled with radioautography on the same cell smears. An extra smear was stained with methyl green pyronine. In some experiments, $\left[{ }^{3} \mathrm{H}\right]$ mannan fixation was evaluated by counting the radioactivity associated with the cells: $1 \times 10^{5}$ cells were collected onto a filter and then counted by liquid scintillation spectrometry.

In certain experiments, medium was removed at day 5 from tetanus toxoid-, Toxoplasma gondii-, SIII-, or PWM-stimulated cultures, and replaced for the last $24 \mathrm{~h}$ by supernatants from mannan-stimulated cultures, in which both IgM and IgG antimannan antibody contents were known (respectively, 35 and $42 \mathrm{U} / \mathrm{ml}$ ).

Inhibition studies. In numerous experiments, before adding $\left[{ }^{3} \mathrm{H}\right]$ mannan, cultured cells were preincubated for $1 \mathrm{~h}$ at $4^{\circ} \mathrm{C}$ or $37^{\circ} \mathrm{C}$ with different carbohydrates: unlabeled mannan from Candida albicans, mannan from Klebsiella, mannose, $\alpha$-methyl-mannoside, oligomannosides, or SIII at concentrations varying from 0.01 to $1 \mathrm{mg} / \mathrm{ml} \mathrm{per} 10^{5}$ cells. Several monoclonal antibodies, i.e., MAb to HLA antigens, anti$\beta_{2}$ microglobulin, OKT3, or UCHT1, OKT4, OKT8, and OKT11, were added at various concentrations $(0.1-10 \mu \mathrm{g} / \mathrm{ml})$, to harvested cells before incubation with $\left[{ }^{3} \mathrm{H}\right]$ mannan.

\section{Results}

In vitro response of sensitized PBL to mannan of Candida albicans. We have previously shown that PBL from CA-sensitized donors are able to mature into specific antimannan ACC when stimulated with mannan absorbed with MBSA or mannan coupled on latex beads. Supernatants of these cultures contain antimannan antibodies (ABs) as detected with an ELISA method. This $\mathrm{Ab}$ response is $\mathrm{T}$ cell-dependent (13 and Table $\mathrm{I}$ ).

Mannan-MBSA or mannan-latex is also able to induce a specific $T$ and $B$ cell proliferation as shown by the analysis of cell surface markers. The proliferation specificity was evidenced by the observation that PBL from unsensitized donors neither proliferate nor mature into antimannan ACC (Table I). Blast cells, as recognized as large pyroninophilic cells, first observed on day 3 of cultures, peaked at day 5. From day 5 to 7 around $50 \%$ of the harvested cells were blast cells. Analysis of cell surface markers showed that $\mathrm{T}$ cell proliferation preceded the proliferation of B lymphocytes. Throughout the incubation period of the cultures, the majority of blast cells were labeled with OKT3 


\begin{tabular}{|c|c|c|c|c|c|c|c|c|c|}
\hline \multirow[b]{3}{*}{ Cultured cells } & & & & \multicolumn{6}{|c|}{ Antimannan antibody in supernatantsł in experiments } \\
\hline & \multicolumn{3}{|c|}{ Antimannan $\mathrm{ACC} *$ in experiments } & \multicolumn{2}{|l|}{1} & \multicolumn{2}{|l|}{2} & \multicolumn{2}{|l|}{3} \\
\hline & 1 & 2 & 3 & IgM & IgG & IgM & IgG & IgM & IgG \\
\hline & & & & $U / m l$ & $U / m l$ & $U / m l$ & $U / m l$ & $U / m l$ & $U / m l$ \\
\hline PBL from unsensitized donors & $<100$ & $<100$ & $<100$ & $<1$ & $<1$ & $<1$ & $<1$ & $<1$ & $<1$ \\
\hline PBL from sensitized donors & 11,400 & 5,700 & 3,600 & 23 & 25 & 15 & 15 & 14 & 5 \\
\hline$E(+)$ from sensitized donors & $<100$ & $<100$ & $<100$ & $<1$ & $<1$ & $<1$ & $<1$ & $<1$ & $<1$ \\
\hline$E(-)$ from sensitized donors§ & 110 & 125 & $<100$ & 3 & 2 & 1 & $<1$ & $<1$ & $<1$ \\
\hline$E(+)$ from sensitized donors + autologous $E(-) \S^{\prime \prime \prime}$ & 8,500 & 6,800 & 5,100 & 17 & 19 & 25 & 16 & 30 & 7 \\
\hline \multicolumn{10}{|l|}{$E(+)$ from sensitized donors + allogeneic $E(-)$} \\
\hline from sensitized donors§."1 & 205 & $<100$ & 105 & 5 & 2 & $<1$ & $<1$ & 2 & 1 \\
\hline
\end{tabular}

Three out of eight experiments yielding similar results are shown. CA-sensitized donors' PBL were cultured for $7 \mathrm{~d}$ in presence of mannan-MBSA $(50 \mu \mathrm{g} / \mathrm{ml})$. Specific response was measured either by: * Enumeration of antimannan ACC revealed by intracytoplasmic radioautography after fixation of $\left[{ }^{3} \mathrm{H}\right]$ mannan (for $1 \times 10^{6}$ input cells). $\ddagger$ Determination of antimannan antibody concentrations by an ELISA in culture supernatants $(\mathrm{U} / \mathrm{ml})$ as compared to the $1: 10,000$ dilution of a reference serum. $\S \mathrm{E}(-)$ populations were depleted of $\mathrm{T}$ lymphocytes by sheep red blood cell rosetting followed by cytotoxicity with OKT 3 plus complement $(<1 \%$ OKT $3(+)$ lymphocytes). Depletion of the excess of monocytes by three successive steps of adherence on plastic did not modify the results. "Cocultures were performed at a ratio of 1:1.

monoclonal antibodies and belonged to $\mathrm{T} 4$ and $\mathrm{T} 8$ subsets, (Fig. $1 A$ ). $\mathrm{SIg}(+)$ blast cells increased progressively from day 3 and bore membrane IgM or IgG, but not IgA or IgD. Antimannan ACC were detected only at day 7 and represented $\sim 4 \%$ of blast cells. An important proportion of blast cells bore HLA class II antigens as revealed by two anti-DR MAbs or the $\mathrm{F}(\mathrm{ab})^{\prime} 2$ fragments of one of them (D1-12) (Fig. $1 A$ ).

Membrane binding of $\left[{ }^{3} H\right]$ mannan on mannan-MBSAinduced blast cells. A proportion of blast cells obtained in stimulated cultures of sensitized PBL, but not of unsensitized PBL including those of newborn infants, was shown to bind $\left[{ }^{3} \mathrm{H}\right]$ mannan. Mannan-binding blasts were already observed on day 3 of cultures; at day 5 , they represented $4 \%$ of harvested

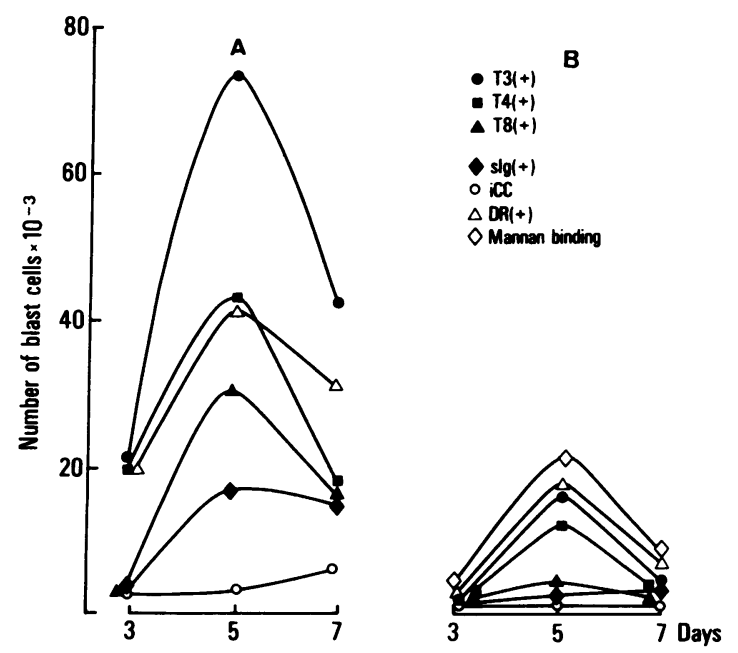

Figure 1. Membrane markers of mannan-induced blast cells. The number of blast cells $(A)$, of mannan-binding blast cells $(B)$ and, among them, the number of cells bearing T3 (๑), T4 (ø), T8 ( $)$, DR $(\Delta)$, sIg ( $\bullet)$, or containing Ig (o), observed at days 3,5 , and 7 of mannan-MBSA $(50 \mu \mathrm{g} / \mathrm{ml})$-stimulated cultures of CA-sensitized donors' leukocytes. cells and 10-20\% of total blast cells, i.e., around 30-40 $\times 10^{3}$ cells for $10^{6}$ input cells (Table II and Fig. $1 B$ ). As shown in Fig. $2 A$, the silver grains (50-200 per cell) were scattered equally over the whole cell surface. The binding of $\left[{ }^{3} \mathrm{H}\right]$ mannan on mannan-stimulated cells was further confirmed by direct evaluation of radioactive counts associated to cells by liquid scintillation (Table II).

Incubation of cultured cells with an excess of CA cold mannan (10 $\mu \mathrm{g}$ to $1 \mathrm{mg}$ ) inhibited the binding of $\left[{ }^{3} \mathrm{H}\right]$ mannan on blast cell membranes. In contrast, incubation with mannose, $\alpha$ methyl-mannoside, oligomannosides, mannan from Klebsiella, or SIII had no effect, even at high concentrations (1 $\mathrm{mg})$ (Fig. 3). The inhibition observed with CA mannan was likewise observed when added before or after the labeled mannan.

As shown on Fig. $4 \mathrm{~A}$, a plateau of mannan-binding concentration was reached when $>10 \mathrm{ng}$ of $\left[{ }^{3} \mathrm{H}\right]$ mannan was added to $1 \times 10^{5} \mathrm{~T}$ cells indicating the saturability of the receptor. Using a scatchard plot analysis, we have been able to estimate the number of receptors per cell, that is around 38,000, with a $K_{\mathrm{D}}$ of $1.9 \times 10^{-6} \mathrm{M}^{-1}$ (Fig. $4 \mathrm{~B}$ ).

Specificity of the mannan binding on blast cell membranes. In order to study mannan-binding specificity, we performed cultures of CA-sensitized PBL stimulated by PWM or by different antigens to which donors were also sensitized. PWM-induced T3(+) blast cells as well as tetanus toxoid (Fig. 2 B), Toxoplasma gondii, or SIII-induced $\mathrm{T} 3(+)$ blast cells did not bind $\left[{ }^{3} \mathrm{H}\right]$ mannan (Table III). Conversely, mannan-induced blast cells did not bind tritiated SIII (Fig. 2 C).

Several experiments were designed in order to examine the hypothesis that the binding of mannan might be secondary to the fixation of antimannan antibodies (secreted during the culture) on Fc receptors expressed on blast cells. Only a low percentage of blast cells harvested on day 3,5, or 7 had detectable Fc $\gamma$ receptors, as studied by immunofluorescence with heataggregated IgG or by rosetting with IgG-sensitized erythrocytes. In addition, the proportion of mannan-binding blast cells was similar both before and after incubation $\left(24 \mathrm{~h}, 37^{\circ} \mathrm{C}\right)$ of cultured $(3,5$, or $7 \mathrm{~d})$ cells in the presence of a supernatant containing 


\begin{tabular}{|c|c|c|c|c|c|c|c|c|c|}
\hline \multirow[b]{2}{*}{ Days of culture } & \multicolumn{3}{|c|}{ Number $\left(\times 10^{-3}\right)^{*}$ of } & \multirow[b]{2}{*}{ Count bound‡ } & \multicolumn{5}{|c|}{ Surface markers of mannan-binding cells $\S$} \\
\hline & Recovered cells & Blast cells & Mannan-binding cells & & slg & $\mathrm{T} 3$ & $\mathrm{~T} 4$ & T8 & $\mathbf{D R}^{\prime \prime}$ \\
\hline & & & & $c p m$ & $\%$ & $\%$ & $\%$ & $\%$ & $\%$ \\
\hline \multicolumn{10}{|l|}{ Exp. 1} \\
\hline 3 & 110 & 37 & 3 & 500 & 1 & 85 & 62 & 20 & 98 \\
\hline 5 & 575 & 237 & 27 & 4,540 & 5 & 80 & 58 & 15 & 75 \\
\hline 7 & 450 & 175 & 15 & 3,950 & 17 & 42 & 20 & 21 & 87 \\
\hline \multicolumn{10}{|l|}{ Exp. 2} \\
\hline 3 & 143 & 29 & 6 & 450 & 2 & 79 & 64 & 19 & 89 \\
\hline 5 & 632 & 240 & 37 & 8,940 & 4 & 71 & 50 & 24 & 83 \\
\hline 7 & 590 & 182 & 12 & 2,700 & 15 & 44 & 10 & 32 & 68 \\
\hline
\end{tabular}

Cells were harvested at different times of mannan-MBSA stimulated cultures and studied for their membrane markers by coupling surface immunofluorescence and radioautography. Two experiments, out of six that gave comparable results, are shown. ${ }^{*}$ Total number for $10^{6}$ input cells. $\ddagger$ Counts per minute for $10^{5}$ cells. $§$ Results are expressed as the percentage of total mannan-binding cells. "DR $(+)$ cells were revealed with the $\mathrm{F}(\mathrm{ab})^{\prime} 2$ fragment of MAb D1-12.

antimannan antibodies: IgM, $35 \mathrm{U} / \mathrm{ml}$ and $\mathrm{IgG}, 42 \mathrm{U} / \mathrm{ml}$. Similarly, PWM or unrelated antigen (tetanus toxoid, Toxoplasma gondii, SIII)-induced blast cels (harvested on day 3, 5, or 7) incubated in the same supernatant remained unable to bind $\left[{ }^{3} \mathrm{H}\right]$ mannan.

Nature of the mannan-binding blast cells. In order to analyze the nature of mannan-binding blast cells, studies were performed by coupling membrane or intracytoplasmic immunofluorescence and radioautography on the same smears observed by microscopy (Table II). The number of mannan-binding blast B cells, detected by membrane staining with an $F(a b)^{\prime} 2$ fragment to human $\mathrm{F}(\mathrm{ab}) \mathrm{IgG}$, gradually increased to reach a level of $15-20 \%$ of blasts on day 7 of the culture. Both $\operatorname{sigM}(+)$ and $\operatorname{sigG}(+)$ bearing blast cells were observed (data not shown). The intracytoplasmic ICC were not detected as $\left[{ }^{3} \mathrm{H}\right]$ mannan-binding cells. A large majority, $\sim 80 \%$, of mannan-binding blast cells analyzed on days 3 and 5 of cultures were T3( + ). Their T cell nature was confirmed by the large reduction (from 27,000 $\pm 9,000$ to $4,000 \pm 1,800$ ) of the number of mannan-binding blast cells in T-depleted populations (by $\mathrm{E}$ rosetting and/or by lysis with OKT3 MAb in presence of complement). The mannan-binding $T$ blast cells were found to be predominantly $\mathrm{T} 4(+)$ on days 3 and 5 while blasts bearing T4 or T8 antigens were found in equal number on day 7 . The mannan-binding cells were not stained by an antimonocyte monoclonal antibody (OKM1) and were not able to phagocytose latex beads.
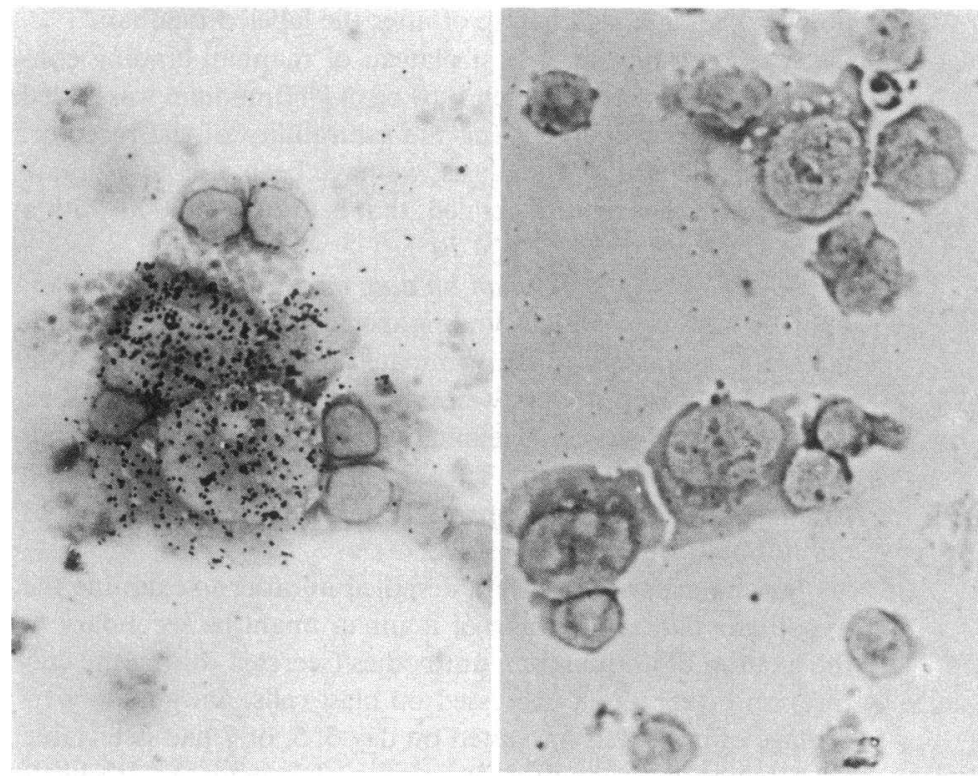

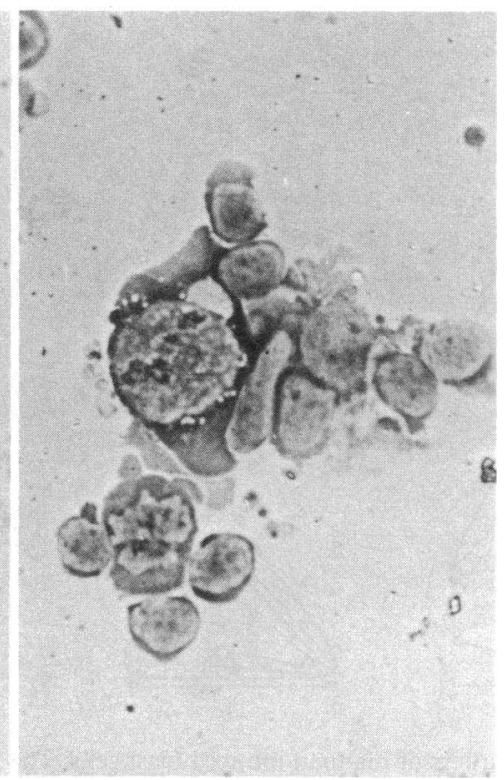

incubation at $4^{\circ} \mathrm{C}$ with $\left[{ }^{3} \mathrm{H}\right]$ mannan. $(C)$ Blast cells observed at day 5 of mannan-MBSA-stimulated cultures and incubated for $1 \mathrm{~h}$ with tritiated SIII. observed at day 5 of tography after a 1 -h incubation at $4^{\circ} \mathrm{C}$ with $\left[{ }^{3} \mathrm{H}\right]$ mannan. $(B)$ Blast cells observed at day 5 of tetanus toxoid-stimulated cultures after a 1-h 


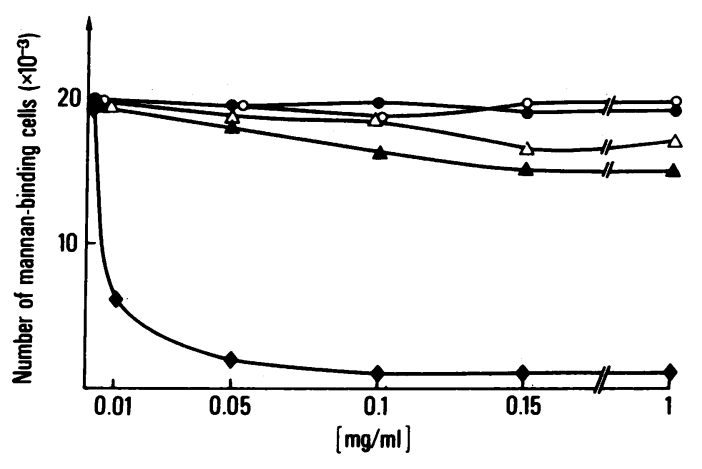

Figure 3. Specificity of mannan binding. Inhibition of the binding of $\left[{ }^{3} \mathrm{H}\right]$ mannan $(0.1 \mu \mathrm{g} / \mathrm{ml})$ on the membrane of 5-d mannan-MBSA-induced blast cells after an incubation with different saccharides: (O) SIII,

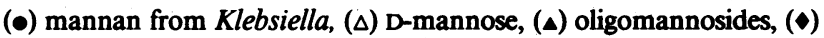
CA unlabeled mannan. Results (of one experiment out of three that gave similar results) are expressed as the absolute number of mannanbinding cells for $1 \times 10^{6}$ input cells.

Most of the mannan-binding blast cells bore HLA-class II antigens as revealed by several anti-DR MAb or their $F(a b)^{\prime} 2$ fragments (Table II, Fig. $1 B$ ).

The $\mathrm{T}$ cell nature of mannan-binding $\mathrm{T} 3(+)$ cells was further shown by two lines of evidence. Mannan-induced T3( + ) blast cells obtained from PBL of three CA-sensitized patients with $\mathrm{X}$-linked agammaglobulinemia (characterized by a complete absence of B lymphocytes) were shown to bind [ $\left.{ }^{3} \mathrm{H}\right]$ mannan on their membranes, although no specific antibodies could be detected in the corresponding supernatants (Table III). The binding of $\left[{ }^{3} \mathrm{H}\right]$ mannan to mannan-specific or influenza virus-specific IL-2-dependent $T$ cell lines has been tested. As studied by both radioautography and liquid scintillation count, the mannan-induced $\mathrm{T}$ cell line only bound $\left[{ }^{3} \mathrm{H}\right]$ mannan consistently, whereas the influenza specific $\mathrm{T}$ cell line did not (Table IV).

In order to know whether mannan binding to its specific receptor needed processing, experiments were performed in which blast cells were fixed with paraformaldehyde (1\%) before incubation with $\left[{ }^{3} \mathrm{H}\right]$ mannan. This procedure did not result in a decrease of mannan binding (data not shown).
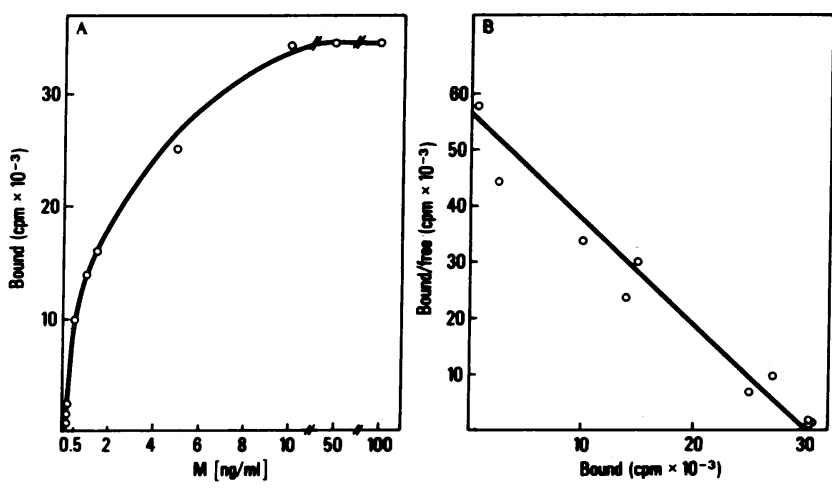

Figure 4. Saturability of mannan binding onto T blast cells. $(A)$ Specific binding of $\left[{ }^{3} \mathrm{H}\right]$ mannan to mannan-specific $\mathrm{IL}-2$-dependent $\mathrm{T}$ cell lines. $(B)$ Scatchard plot of $\left[{ }^{3} \mathrm{H}\right]$ mannan binding. $1 \times 10^{5} \mathrm{~T}$ cells were incubated for $1 \mathrm{~h}$ in $100 \mu \mathrm{l}$ of phosphate-buffered saline with the indicated concentration of $\left[{ }^{3} \mathrm{H}\right]$ mannan. The data shown in the Scatchard plot are derived from $A$. The slope has been determined by the least square method. One of two similar experiments is herein shown.
Anti-T3 monoclonal antibodies block mannan binding to $T$ cells. Experiments were performed in order to define the relationship between known membrane glycoproteins and the mannan binding structure of blast cells. As shown in Fig. 5, MAbs to $\mathrm{T}$ cell antigen T3 (OKT3 or UCHT1) were shown to inhibit the membrane binding of $\left[{ }^{3} \mathrm{H}\right]$ mannan on $\mathrm{T} 3(+)$ and not on $\operatorname{sig}(+)$ blast cells when preincubated at $37^{\circ} \mathrm{C}$ but not at $4^{\circ} \mathrm{C}$. The inhibition was complete at a concentration of $2 \mu \mathrm{g} / \mathrm{ml}$ of MAb (OKT3, or UCHT1) and was dependent upon the amount of MAb added. In contrast, MAb OKT4, OKT8, and OKT11 did not inhibit the mannan binding (neither at $4^{\circ} \mathrm{C}$ nor at $37^{\circ} \mathrm{C}$ ), even at concentrations up to $10 \mu \mathrm{g} / \mathrm{ml}$ ). Similarly, MAb antiHLA class I molecules (W-6/32), anti- $\beta_{2}$-microglobulin (0.18) (data not shown), or anti-HLA-DR molecules (D1-12 or OKIa1) did not alter mannan binding on blasts. Some degree of inhibition was observed using HLA-DQ MAb (SDR1-BT 3/4) (Fig. 5).

Consequences of mannan binding onto $T$ cells. In order to evaluate the possible functional effect of mannan binding onto $T$ cells, we attempted to determine whether mannan binding to $T$ cells can induce either $T$ cell proliferation or conversely an unresponsiveness to mannan. As shown in Table V, mannanspecific IL-2-dependent $T$ cells able to bind mannan on their membranes (Table IV) did not proliferate when cultured in presence of mannan in the absence of monocytes. Furthermore, after a similar incubation, these $\mathrm{T}$ cells were unable to proliferate when further stimulated with mannan in the presence of monocytes, whereas the same $T$ cells not previously incubated with mannan kept a strong proliferative ability (Table $\mathrm{V}$ ).

\section{Discussion}

We have shown that mannan-stimulated blast $\mathrm{T}$ cells obtained in short- or long-term cultures were able to specifically bind $\left[{ }^{3} \mathrm{H}\right]$ mannan. A pulse of unlabeled mannan completely inhibited the mannan binding on blast cells; indicating that the labeling procedure of mannan did not alter its structure. A combined radioautography-immunofluorescence technique permitted the identification of blast subsets able to bind labeled mannan on their membranes. $\left[{ }^{3} \mathrm{H}\right]$ mannan-binding $\mathrm{T}$ blast cells were detected early in short-term-stimulated cultures and peaked at day 5 . Whether the short-term $T$ blast cells that do not bind mannan are unspecifically activated or whether they express a smaller number of membrane receptors or, alternatively, express receptors with a weaker affinity for the antigen, remains unelucidated. In contrast, most of the long-term-cultured, mannan-specific proliferative $\mathrm{T}$ blasts bound mannan. Although in vitro induction of antigen-binding $T$ blast cells has been described in several different systems (1-7), it has given rise to much controversy. However, a direct binding of antigen to a human $T$ cell clone specific for a peptide of influenza hemagglutinin has been recently shown (29). We therefore focused our attention on the specificity of mannan binding. Short-term blasts or antigen-specific long-term IL-2-dependent $T$ lymphocytes induced by different antigens unrelated to mannan, did not bind $\left[{ }^{3} \mathrm{H}\right]$ mannan. These observations, together with the absence of inhibition of the $\left[{ }^{3} \mathrm{H}\right]$ mannan binding by mannose, excludes a nonspecific binding of mannan on a cell surface lectin (30). One could have envisaged that mannan interacts nonspecifically with the T3 molecule, which would have explained the blocking effect of anti-T3 MAb, in that lectins such as concanavalin A bind the T3 molecule (31). However, the specific binding of mannan to 


\begin{tabular}{|c|c|c|c|c|c|c|c|}
\hline \multirow[b]{2}{*}{ Lymphocytes from } & \multirow[b]{2}{*}{$\begin{array}{l}\text { Cultures stimulated } \\
\text { with }\end{array}$} & \multicolumn{3}{|c|}{ Mannan-binding $\mathrm{T}$ blast cell* in experiments } & \multicolumn{3}{|c|}{ Antimannan $A C C \ddagger$ in experiments } \\
\hline & & 1 & 2 & 3 & 1 & 2 & 3 \\
\hline Unsensitized donors & Mannan-MBSA & $<100$ & $<100$ & $<100$ & $<100$ & $<100$ & $<100$ \\
\hline CA sensitized donors & Mannan-MBSA & 27,000 & 37,000 & 17,000 & 11,400 & 5,700 & 3,600 \\
\hline CA sensitized donors & PWM & $<100$ & $<100$ & $<100$ & $<100$ & $<100$ & $<100$ \\
\hline CA sensitized donors & Tetanus toxoid & $<100$ & $<100$ & $<100$ & $<100$ & $<100$ & $<100$ \\
\hline CA sensitized donors & Toxoplasma & $<100$ & $<100$ & $<100$ & $<100$ & $<100$ & $<100$ \\
\hline CA sensitized donors & SIII & $<100$ & $<100$ & $<100$ & $<100$ & $<100$ & $<100$ \\
\hline Agammaglobulinemic patients§ & Mannan-MBSA & 18,000 & 17,000 & 19,000 & $<100$ & $<100$ & $<100$ \\
\hline
\end{tabular}

Cells were harvested in order to study both the mannan binding on T (OKT3(+)) blast cells and the antimannan ACC. Results are the number of harvested cells for $1 \times 10^{6}$ input cells. * Number of mannan-binding blast $T$ cells recovered at day 5 of the culture. $¥$ Number of antimannan ACC recovered at day 7 of the culture. $\S$ These three patients were affected with an X-linked agammaglobulinemia (without B cells).

cells previously activated by the same antigen rule out this hypothesis. We were able to demonstrate that the mannan binding on $\mathrm{T}$ blast cells was not mediated through the fixation of antimannan antibodies to Fc $\mu$ or $\gamma$ membrane receptors.

Several data strongly support the notion of the existence of a true specific receptor for mannan onto specifically activated $T$ cells. First, binding has been shown to be reversible. Second, it is possible to saturate the binding ability of membrane receptors allowing an evaluation of the number of mannan-binding receptors per cell, as well as the avidity of the receptors. Attempts at blocking the mannan binding using oligomannosides sharing two types of covalent linkages with CA mannan ( $\alpha 1-2, \alpha 1-3)$ failed. These results suggest that other part(s) of the molecule may be seen by the $T$ cells. Further experiments using other oligomannosides are thus required to define precisely the epitopic structure recognized by mannan-specific $T$ cells. Finally, we have shown that mannan binding onto specifically activated $T$ cells results in further unresponsiveness to mannan. These results are very similar to those observed in the tolerance-induction experiment of influenza peptide-specific $T$ cell clones by Zanders et al. (14). In addition, mannan binding alone did not induce $T$ cell proliferation, either because accessory cells are required or because of tolerance induction in the absence of monocytes.

It is likely that the observation of a specific binding of antigen to $\mathrm{T}$ blast cells was made possible, as in the study reported by Zanders et al. (29), through the use of a highly labeled antigen.
It is a somewhat unexpected finding that free mannan alone could specifically bind $\mathrm{T}$ lymphocyte membranes because it has previously been demonstrated that the $\mathrm{T}$ cell receptor is specific for antigen associated with a MHC product (8-12). Such an association is indeed required for mannan inasmuch as monocyte- $T$ lymphocyte interactions in mannan-induced $T$ cell responses are HLA class II-restricted (32). The probable multivalence of mannan epitope(s) recognized by $T$ cells may permit a sufficient cross-linking of the antigen receptor, allowing its direct visualization with $\left[{ }^{3} \mathrm{H}\right]$ mannan, despite a likely low affinity in the absence of HLA class II molecules, as suggested in a mouse model in which $\mathrm{T}$ cell clones can bind hapten fluorescein isothiocyanate (33). An alternative hypothesis could be that specific $T$ lymphocytes recognize mannan in association with HLA class II molecules expressed by the activated $T$ lymphocytes as suggested by others (29). The fact that anti-HLA-DQ monoclonal antibodies did partially inhibit the binding of mannan to $T$ cells is in accordance with this suggestion. Indeed, we have previously shown that mannan-induced specific $T$ cell proliferation and specific B cell maturation are HLA-DQ-restricted (32). The inhibition of mannan-binding by anti-DQ antibodies could suggest a cross-reactivity between mannan determinants and HLA-DQ. This is not the case since two anti-HLA-DQ (SDR 1 and leu 10) monoclonal antibodies were shown not to react with mannan in an inhibition ELISA assay of the binding of antimannan antibodies to mannan (data not shown). One could thus envisage

Table IV. Mannan Binding on IL-2-dependent T Cell Lines

\begin{tabular}{|c|c|c|c|c|c|c|c|}
\hline \multirow{3}{*}{$\begin{array}{l}\mathrm{T} \text { cell lines } \\
\text { initiated with }\end{array}$} & \multicolumn{4}{|c|}{ Mannan binding } & \multirow{2}{*}{\multicolumn{3}{|c|}{ Proliferation toł }} \\
\hline & \multicolumn{2}{|l|}{ Cells (+) } & \multicolumn{2}{|l|}{ Count bound* } & & & \multirow[b]{2}{*}{$\begin{array}{l}\text { Influenza } \\
\text { virus }\end{array}$} \\
\hline & Week 4 & Week 8 & Week 4 & Week 8 & IL-2 & $\begin{array}{l}\text { Mannan } \\
\text { (week 8) }\end{array}$ & \\
\hline & $\%$ & $\%$ & $c p m$ & cpm & $c p m \times 10^{3}$ & $c p m \times 10^{3}$ & $c p m \times 10^{3}$ \\
\hline Mannan-MBSA & 75 & 98 & $19,990 \pm 2,800$ & $27,450 \pm 3,500$ & $17 \pm 2$ & $22 \pm 2$ & $0.8 \pm 0.6$ \\
\hline Influenza virus & $<1$ & $<1$ & $516 \pm 90$ & $450 \pm 73$ & $10.5 \pm 2$ & $0.6 \pm 3$ & $9.5 \pm 1$ \\
\hline
\end{tabular}

IL-2 dependent specific T cell lines were analyzed 4-8 wks after their initiation. Membrane markers studies revealed that $>90 \%$ of cells were T3 $(+) \mathrm{T} 4(+)$. ${ }^{*}$ For $1 \times 10^{5} \mathrm{~T}$ blast cells. $¥ 10^{4} \mathrm{~T}$ cells were cultured for $3 \mathrm{~d}$ with 4,000-rad-irradiated autologous PBL in presence of either medium alone, IL-2 medium, mannan-MBSA $(50 \mu \mathrm{g} / \mathrm{ml})$, influenza virus $(0.5 \mu \mathrm{g} / \mathrm{ml})$. $\left[{ }^{3} \mathrm{H}\right] \mathrm{TdR}$ uptake in cultures performed in medium alone was below $1,000 \mathrm{cpm}$. 


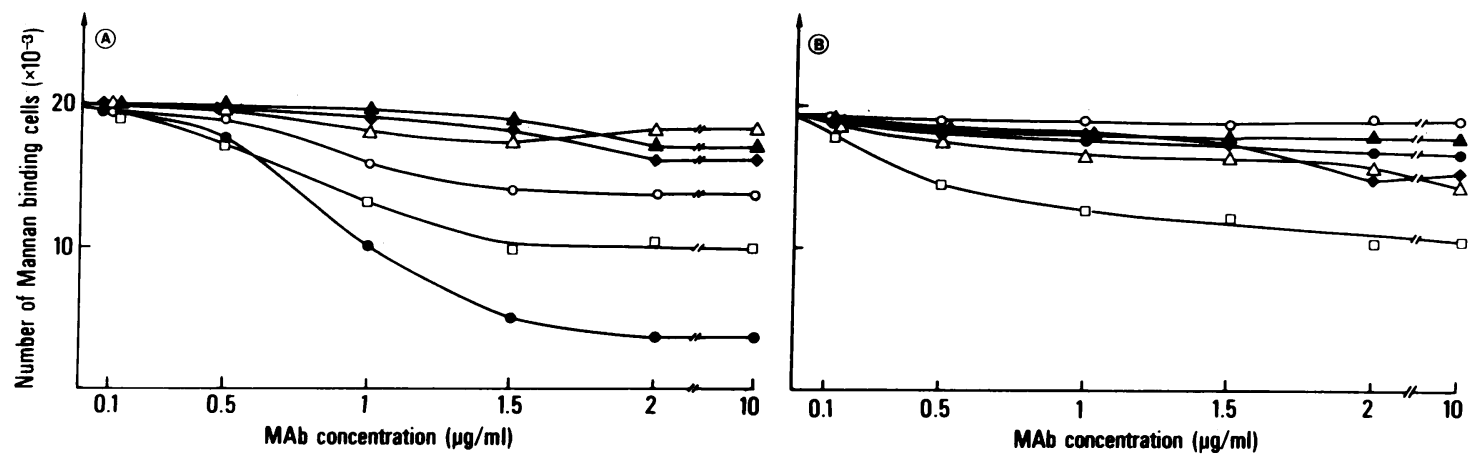

Figure 5. Relationship of mannan binding with T cell glycoproteins. Inhibition of the mannan binding on the membrane of 5-d mannanMBSA-induced blast cells from a HLA-DQW1 homozygous subjects after an incubation with different MAbs performed $(A)$ at $37^{\circ} \mathrm{C},(B)$ at $4^{\circ} \mathrm{C}$. Results of one experiment out of six that gave similar results are

expressed as the total number of labeled cells for $1 \times 10^{6}$ input cells.

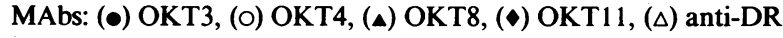
D 1-12 (similar results were obtained with OKIa 1), (口) anti-DQ SDR 1 (similar results with BT 3-4).

that the specific receptor sees mannan associated with an HLADQ molecule at the surface of monocytes or B lymphocytes in short-term cultures or activated $\mathrm{T}$ cells in long-term cultures. The ability of fixed blast $\mathrm{T}$ cells to bind $\left[{ }^{3} \mathrm{H}\right]$ mannan clearly indicates that binding to the specific receptor does not need mannan processing. Whether the direct detection of the specific antigen receptor through the use of a labeled antigen can be observed for other antigens with repetitive units is not yet known. Preliminary experiments using tritiated pneumococcal polysaccharide with a repetitive glucose-glucuronic acid sequence have shown specific binding to SIII-activated T cells (unpublished data).

The relationship between the specific antigen-binding structures and well-defined glycoproteins expressed on T cell membranes was studied by inhibition experiments with several specific antisera. Recent works have strongly suggested a role of the membrane glycoprotein recognized by the OKT3 and UCHT1 monoclonal antibodies in the induction of $\mathrm{T}$ cell responses. It has been demonstrated first that OKT 3 is a potent mitogen for $\mathrm{T}$ cells (31), and secondly that there is a close relationship between the 20,000-28,000-mol wt glycoprotein complex recog-

nized by OKT 3 or UCHT1 and the antigen-specific T cell receptor (12-14). Bensussan et al. have shown that there is a common modulation of both receptors (11), and Zanders et al. have shown the direct inhibitory activity of antibody to T3 molecule on antigen-induced proliferation of $T$ cell clones (14). In accordance with these results, we observed an inhibitory activity of OKT3 and UCHT1 (but not of OKT4, OKT8, or OKT11) monoclonal antibodies on mannan binding to $T$ blast cell membranes. Because the inhibitory effect occurred at $37^{\circ} \mathrm{C}$, but not at $4^{\circ} \mathrm{C}$, it is more likely due to a modulation of the mannanbinding material than to a steric hindrance.

The level of $\left[{ }^{3} \mathrm{H}\right]$ mannan binding to $\mathrm{T}$ cells was found around $6.1 \times 10^{-15}$ mol for $1 \times 10^{5}$ mannan-specific $\mathrm{T}$ cells, which corresponds to $\sim 3.8 \times 10^{4}$ mannan molecules bound per cell. Although corresponding to a minimal evaluation of the number of receptors for mannan because of the possible multivalence of this molecule, this figure appears to be within the range of the number of antigen receptors on $T$ cells found in humans $\left(5 \times 10^{4}\right)(29)$ or in mice $\left(4 \times 10^{4}\right)(10)$.

Our results give evidence of a membrane structure on mannan-induced $T$ blast cells that specifically binds the antigen. The

Table V. Consequences of the Mannan Binding onto T Cells

\begin{tabular}{|c|c|c|c|c|c|}
\hline \multirow[b]{3}{*}{ Cultured cells } & \multirow{3}{*}{$\begin{array}{l}\text { Monocytes added } \\
\text { during the culture }\end{array}$} & \multicolumn{4}{|c|}{ Cell proliferation induced by } \\
\hline & & \multicolumn{2}{|c|}{ Mannan } & \multicolumn{2}{|l|}{ IL-2 } \\
\hline & & Exp. 1 & Exp. 2 & Exp. 1 & Exp. 2 \\
\hline $\mathbf{T}$ cell lines & - & 703 & 188 & 10,058 & 8,220 \\
\hline $\mathrm{T}$ cell lines & + & 8,542 & 4,390 & 18,899 & 10,790 \\
\hline \multicolumn{6}{|c|}{$\mathrm{T}$ cell lines preincubated with } \\
\hline 0 & + & 6,840 & 4,900 & 12,500 & 12,290 \\
\hline Mannan $1 \mu \mathrm{g}$ & + & 1,800 & 945 & 10,903 & 16,375 \\
\hline Mannan $10 \mu \mathrm{g}$ & + & 544 & 980 & 12,079 & 16,450 \\
\hline Mannan $100 \mu \mathrm{g}$ & + & 547 & 660 & 12,460 & 10,360 \\
\hline
\end{tabular}

Mannan-specific T cell lines (104) were cultured for $3 \mathrm{~d}$ with (or without) 4,000-rad-irradiated autologous PBL $\left(5 \times 10^{4}\right)$ in presence of mannanMBSA $(50 \mu \mathrm{g} / \mathrm{ml})$ or IL-2 medium. In the second group of experiments, T cell lines had been preincubated for $24 \mathrm{~h}$ at $37^{\circ} \mathrm{C}$ with (or without) mannan at different concentrations, then extensively washed and cultured again with antigen or IL-2 medium. In each experiment, background proliferation (without antigen or IL-2) was below $300 \mathrm{cpm}$. 
detection of this membrane structure provides a useful model for studying the regulation of its expression by various reagents and immunoregulatory products.

\section{Acknowledgments}

We are grateful to $\mathrm{E}$. Drouhet for the kind gift of CA mannan, J. Montreuil for the kind gift of oligomannosides, and V. Kato for providing Klebsiella mannan. We thank Mrs. M. Forveille and A. M. Laharie for their excellent technical assistance as well as Ms. V. Serrurier and Mrs. B. Rougier for their skillful secretarial assistance.

This work was supported by The Institut National de la Santé et de la Recherche Médicale and by The Conseil Scientifique Université Paris V.

\section{References}

1. Wilson, J. D., and J. F. A. P. Miller. 1971. T and B rosette forming cells. Eur. J. Immunol. 1:501-503.

2. Ashman, R. E., and M. C. Raff. 1973. Direct demonstration of theta-positive antigen-binding cells, with antigen-induced movement of thymus-dependent cell receptors. J. Exp. Med. 137:69-84.

3. Hammerling, G. J., and H. O. McDevitt. 1974. Antigen-binding $T$ and $B$ lymphocytes. I. Differences in cellular specificity and influence of metabolic activity on interaction of antigen with $\mathrm{T}$ and $\mathrm{B}$ cells. $J$. Immunol. 112:1726-1731.

4. Rubin, B., B. Hertel-Wulff, and A. Kimara. 1979. Alloantigenspecific idiotype-bearing receptors on mouse T lymphocytes. J. Exp. Med. 150:307-321.

5. Binz, H., and H. J. Wigzell. 1980. T cell receptors with allo-major histocompatibility complex specificity from rat and mouse. J. Exp. Med. 154:1261-1277.

6. Lea, T., and T. E. Michaelson. 1982. Anti-VH antibodies interfere with antigen binding by human $\mathrm{T}$ lymphocytes. Clin. Exp. Immunol. 49:657-664.

7. Lehner, T. 1983. Antigen binding human T suppressor cells and their association with the HLA-Dr locus. Eur. J. Immunol. 13:370-378.

8. Bergholtz, B. D., and E. Thorsby. 1978. HLA-D restriction of the macrophage dependent response of immune human $\mathrm{T}$ lymphocytes in vitro inhibition by anti-HLA DR antisera. Scand. J. Immunol. 8:63-74.

9. Fischer, A., P. C. L. Beverley, and M. Feldmann. 1981. Longterm human $T$ helper lines producing specific helper factor reactive to influenza virus. Nature (Lond.). 294:166-168.

10. Haskins, K., R. Kubo, J. Hite, M. Pigeon, J. Kappler, and P. Marrack. 1983. The major histocompatibility complex-restricted antigen receptor on T cells. I Isolation with a monoclonal antibody. J. Exp. Med. 157:1149-1169.

11. Bensussan, A., S. C. Meuer, S. F. Schlossman, and E. L. Reinherz. 1984. Delineation of an immunoregulatory amplifier population recognizing autologus Ia molecules. Analysis with human $T$ cell clones. $J$. Exp. Med. 159:559-576.

12. Meuer, S. C., K. A. Fitzgerald, R. E. Hussey, J. C. Hodgdon, S. F. Schlossman, and E. L. Reinherz. 1983. Clonotypic structures involved in antigen specific human $T$ cell function. Relationship to the T3 molecules complex. J. Exp. Med. 157:705-719.

13. Durandy, A., A. Fischer, and C. Griscelli. 1983. Specific in vitro anti-mannan rich antigen of Candida albicans antibody production by sensitized human blood lymphocytes. J. Clin. Invest. 71:1602-1613.

14. Zanders, E. D., J. R. Lamb, M. Feldmann, M. Green, and P. C. L. Beverley. 1983. Tolerance of T cell clones is associated with membrane antigen changes. Nature (Lond.). 303:625-627.
15. Summers, D. F., A. P. Grollman, and H. F. Hasenclever. 1964. Polysaccharide antigens of Candida cell wall. J. Immunol. 92:491-499.

16. Aspinall, G. O. 1983. The chemistry of polysaccharides of fungi and lichens. In The polysaccharides. Vol. 2. Academic Press, Inc. New York. 365-400.

17. Felton, L. D., B. Prescott, G. Kaufman, and B. Ottinger. 1955. Pneumococcal antigenic polysaccharide substances from animal tissues. J. Immunol. 74:205-210.

18. Evans, E. A., H. C. Sheppard, S. C. Turner, and D. C. Warrel. 1974. A new approach to specific labelling of organic compounds with tritium gas. J. Labelled Compd. 10:569-575.

19. Gettner, S. M., and D. A. Mackenzie. 1981. Response of human peripheral lymphocytes to soluble and insoluble antigens of Candida Albicans. J. Med. Microbiol. 14:333-336.

20. Fischer, A., G. Sterkers, D. Charron, and A. Durandy. 1985. HLA-class II restriction governing cell cooperation between antigen-specific helper $\mathrm{T}$ lymphocytes, $\mathrm{B}$ lymphocytes and monocytes for in vitro antibody production to influenza virus. Eur. J. Immunol. 15:620-626.

21. Kurnick, J., P. Alteuogt, J. Lindblom, O. Sjoberg, A. Danneus, and H: Wigzell. 1979. Long-term maintenance of HLA-D restricted T cells specific for soluble antigens. Scand. J. Immunol. 11:131-136.

22. Reinherz, E. L., and S. F. Schlossman. 1980. The differenciation and function of human T lymphocytes. Cell. 19:821-825.

23. Breard, J., E. L. Reinherz, P. C. Kung, G. Goldstein, and S. F. Schlossman. 1980. A monoclonal antibody reactive with human peripheral blood monocytes. J. Immunol. 124:1943-1948.

24. Beverley, P. C. L., and R. E. Callard. 1981. Distinctive functional characteristics of human $\mathrm{T}$ lymphocytes defined by $\mathrm{E}$ rosetting or a monoclonal anti-T cell antibody. Eur. J. Immunol. 11:329-334.

25. Reinherz, E. L., P. C. Kung, J. M. Pesando, J. Ritz, G. Goldstein, and J. F. Schlossman. 1979. Ia-determinants on human T cell subsets defined by monoclonal antibody. J. Exp. Med. 150:1472-1482.

26. Charron, D. J. 1984. Serology with 100 monoclonal antibodies to MHC class II antigens: an overview of workshop presentations. Dis. markers. 2:145-150.

27. Durandy, A., J. L. Virelizier, and C. Griscelli. 1983. Enhancement by interferon of membrane HLA antigens in patients with combined immunodeficiency with defective HLA expression. Clin. Exp. Immunol. 52:173-178.

28. Moretta, L., S. Webb, C. Grossi, P. M. Lydyard, and M. D. Copper. 1977. Functional analysis of two human T-cell subpopulations: help and suppression of $B$ cell responses by $T$ cells bearing receptors of $\operatorname{IgM}(\mathrm{T} \mu)$ or IgG (T $\gamma)$. J. Exp. Med. 146:184-200.

29. Zanders, E. D., M. Feldmann, M. Green, and J. R. Lamb. 1984. Direct evaluation of antigen binding to human $\mathrm{T}$ lymphocytes clones: involvement of major histocompatibility complex products in antigen binding. Eur. J. Immunol. 14:1101-1105.

30. Monsigny, M., C. Kieda, and A. C. Roche. 1983. Membrane glycoproteins, glycolipids and membrane lectins as recognition signals in normal and malignant cells. Biol. Cell. 47:95-99.

31. Kanellopoulos, J. M., S. D. de Petris, G. Leca, and M. J. Crumpton. 1985. The mitogenic lectin form Phaseolus vulgaris does not recognize the T3 antigen of human T lymphocytes. Eur. J. Immunol. 15: 479-486.

32. Durandy, A., A. Fischer, and C. Griscelli. 1986. Restriction of the in vitro anti-mannan antibody response by HLA-DQ molecules. Hum. Immunol. In press.

33. Siliciano R., A. Keegan, R. Dintzis, H. Dintzis, and H. Shin. 1985. The interaction of nominal antigen with $T$ cell antigen receptors. I-specific binding of multivalent nominal antigen to cytolytic $T$ cell clones. J. Immunol. 135:906-914. 